\title{
A ética protestante no contexto contemporâneo
}

\author{
Martin Riesebrodt \\ Tradução de Norma Caroline Demamann Müller
}

Nenhum texto de Max Weber foi tão lido, tão controversamente discutido e tão mal compreendido como seu artigo "Die Protestantische Ethik und der 'Geist' des Kapitalismus" [A ética protestante e o "espírito" do capitalismo $]^{1}$. Para uns, ele representa uma obra-prima, cuja tese central serviu de base para teorias da modernização (cf. Eisenstadt, 1968). Para outros, a "Ética protestante" é um ataque idealista à teoria histórica e social de Marx e, em consequência, não apenas falsa, mas também ideologicamente motivada. Nenhuma dessas leituras faz justiça ao texto. Via de regra, também os historiadores que se debruçaram criticamente sobre Weber não acertaram o núcleo da tese, ao supor que ele pretendesse uma explicação da gênese do capitalismo enquanto um sistema econômico. Também o interpreta mal aquele que, inadvertidamente, testa a argumentação de Weber nos locais em que se encontravam os capitalistas mais bem-sucedidos. O próprio Weber já empenhara muitos esforços para aclarar tais mal-entendidos (cf. Weber, 1910).

Weber não trata de "capitães da economia" e suas receitas de sucesso, mas sim das origens de uma nova visão do trabalho que contribuiu para o sistema do capitalismo empresarial moderno e, dessa maneira, alcançou um efeito de massa. Portanto, o que está em debate é um fenômeno cultural que, a longo prazo, também teve repercussão sobre as estruturas econômicas, um novo éthos, que representa a quebra da visão tradicional do trabalho e da atividade econômica. A disposição interna dos seres humanos foi revolucionada e a dedi-

1. Cito de acordo com a primeira versão recentemente editada por Klaus Lichtblau e Johannes Weiss (cf. Weber, 1993b). 
cação ao trabalho tornou-se central. Weber acredita poder identificar as origens dessa revolução no "protestantismo ascético", que associou, na profissão, a esperança de salvação religiosa à comprovação intramundana. Esse protestantismo ascético transforma-se mais tarde em utilitarismo, embrenhando-se, como expectativa de comportamento institucionalizado, nas "capas rígidas de aço" do capitalismo moderno.

Não se trata de provar aqui que Weber tinha razão (cf. Graf, 1993). Essa é uma questão que, em última instância, só historiadores podem responder, desde que compreendam os argumentos de Weber. Para mim, trata-se muito mais de contextualizar o ensaio de Weber, ou seja, enraizá-lo no debate científico e político sobre o capitalismo por volta de 1900, assim como evidenciar uma dimensão pessoal do texto. Tal contextualização deve facilitar a compreensão da "Ética protestante".

\section{A "Ética protestante": dois textos}

A dificuldade de uma leitura da "Ética protestante" não diz respeito apenas ao leitor, mas também ao texto. Pois, a rigor, a "Ética protestante" não é um texto, mas dois. A primeira versão foi publicada como sequência de dois artigos no outono de 1904 e no inverno de 1905 no Archiv für Sozialwissenschaft und Sozialpolitik [Arquivo para a ciência social e a política social]. A segunda versão apresenta uma leve revisão da primeira e foi inserida, em 1920, no primeiro volume dos Gesammelte Aufsätze zur Religionssoziologie [Ensaios reunidos sobre sociologia da religião] de Weber, que reúne, ao lado da "Ética protestante" e do artigo sobre seitas protestantes, os textos sobre a "Wirtschaftsethik der Weltreligionen" [Ética econômica das religiões universais], que tratam das racionalidades da ação e das motivaçôes religiosas da ação das religiões da China e da Índia e do judaísmo antigo (cf. Weber, 1920a). Uma introdução tem o papel de elucidar e sumarizar o programa de pesquisa que está na base desses estudos (cf. Idem, vol. 1, pp. 1-16).

Embora a segunda versão da "Ética protestante" se diferencie da primeira apenas por alguns aditamentos em que Weber discute novas publicaçôes, como as de Lujo Brentano e Werner Sombart, o contexto altera-se fundamentalmente. Desse modo, a introdução aos Ensaios reunidos sobre sociologia da religiāo, que com muita frequência é mal entendida como uma introdução à "Ética protestante", formula teses sobre a singularidade da racionalidade ocidental. Contudo, o texto subsequente, a "Ética protestante", não cumpre absolutamente essa pretensão grandiosa. De mais a mais, do ponto de vista 
sociológico, a "Ética protestante" fica aquém dos textos da "Ética econômica das religiōes universais". Embora a "Ética protestante" certamente representasse para Weber um estímulo para mais tarde dedicar-se à "Ética econômica das religiōes universais", ele procede nesses textos de forma diferente. Os estudos das religiōes da China, da Índia e do judaísmo antigo iniciam-se todos com uma análise da estrutura social, com a intenção de identificar os variados estratos de portadores de posturas especificamente religiosas diante do mundo. O resultado é sumarizado por Weber de modo sistemático no capítulo sobre sociologia da religião de "Wirtschaft und Gesellschaft" [Economia e sociedade].

$\mathrm{Na}$ "Ética protestante", contudo, falta essa ancoragem na estrutura social e a cuidadosa identificação de um estrato de portadores, o que certamente levou a mal-entendidos, que Weber procurou dar conta em trabalhos posteriores sobre a burguesia do Ocidente. Na "Ética protestante", Weber se contenta com breves remissões ao pequeno empresariado em ascensão. Além disso, a compreensão de Weber dos processos civilizatórios ampliou-se da análise da cultura capitalista para uma análise das posturas básicas diante do mundo e, como consequência, para direçōes variadas dos processos de racionalização.

Por fim, entre 1904 e 1920 também as circunstâncias históricas e políticas se alteraram enormemente. A primeira versão da "Ética protestante" foi publicada em um momento em que a Alemanha tinha experimentado um rápido crescimento econômico, convertido pelos nacionalistas em pretensōes de grande potência. A publicação da segunda versão surgiu quando, depois de perdida a guerra, a Alemanha, econômica e socialmente quebrada, encontrava-se em um estado similar a uma guerra civil. Sob condiçôes tão diferentes, a discussão acerca do significado de capitalismo ou "espírito" do capitalismo será, com certeza, diversa.

Em outras palavras, o texto da "Ética protestante", com modificações mínimas, é situado adequadamente no contexto de 1920 como precursor e incitador dos estudos sobre a "Ética econômica das religiōes universais". Mas a tentativa de engatar a "Ética protestante" aos estudos da "Ética econômica das religiôes universais” por meio de uma nova introdução é excessiva. $\mathrm{O}$ texto não fora formulado nem para a discussão política daquela época, nem como pertencendo à "Ética econômica das religiōes universais". Por isso, a "Ética protestante" é mais bem compreendida no contexto de 1904-1905, em que foi originalmente escrita, do que no contexto posterior. 
O contexto da "Ética protestante" de 1904-1905

$\mathrm{Na}$ época da primeira edição, a Alemanha encontrava-se em uma transição, vivenciada por todas as classes como problemática, de um estado agrário para um estado industrial, e do princípio de dominação pessoal para o burocrático. Uma multiplicidade de classes e grupos sociais rejeitava a modernidade ocidental, marcada pelo capitalismo, pela burocracia, pela democracia e pela sociedade de massas. A aristocracia sentia falta dos "bons e velhos tempos", em que o nome garantia domínio e privilégios. A burguesia temia o operariado em ascensão, que lutava por igualdade de direitos políticos e melhoria de suas condições materiais de vida. A pequena burguesia de negociantes e artesãos sentia-se ameaçada pelo capitalismo industrial e pelos investidores financeiros. A Igreja luterana, e especialmente o Estado prussiano, via-se ameaçado, por um lado, pela Igreja católica e pelo catolicismo organizado, e, por outro, pelo "socialismo ateísta", que haviam sido combatidos em vão na "Kulturkampf" (luta cultural, 1871-1878) e nas leis antissocialistas (1878-1890).

Esses desenvolvimentos e atmosferas tiveram também influência evidente sobre os intelectuais e cientistas, tanto pessoal como institucionalmente. Nem todos tentaram analisar de forma sóbria e científica a transformação radical e tirar disso conclusões racionais para a organização da sociedade e também para suas próprias vidas. A criação de mitos e a autoestilização proliferaram. Alguns intelectuais viraram as costas para a política e o comércio e estilizaram-se como uma nova aristocracia do espírito. Outros refugiaram-se no messianismo religioso ou na promessa de salvação oriental, na liberação da sexualidade das normas burguesas, no vegetarianismo como fonte de pureza física e espiritual, no retorno romântico à natureza do movimento de juventude (Jugendbewegung) ou no anarquismo (cf. Karádi, 1987). Outros, sonhavam com o retorno ao passado místico, em que a "solidariedade germânica" ainda não tivesse sido corrompida pelo direito romano ou pelos "judeus", que ironicamente foram responsabilizados tanto pelo capitalismo como pelo socialismo. A nação representava a comunidade íntegra, que guardava a fraternidade germânica "autêntica" contra a invasão do "estrangeiro" e assim poderia opor-se à modernização capitalista.

Nessa situação de desorientação cultural, Max Weber esforça-se, em seus escritos, para tornar a discussão objetiva e desmascarar mitos. Ele o faz, por exemplo, em suas análises sobre a transformação da Prússia rural, em seus estudos sobre a bolsa, em seus ensaios sobre o direito românico e 
germânico, assim como na "Ética protestante". Ao mesmo tempo, passa a tematizar a questão de com quais teorias e métodos a história poderia ser explicada e compreendida - discussão em que seu interlocutor implícito é com frequência Karl Marx. E, por fim, ele se ocupa do problema de como se poderia levar uma vida digna e plena de sentido sob as condições da modernidade. Aqui a "Ética protestante" é uma precursora dos futuros discursos sobre a "Ciência como profissão" e a "Política como profissão".

Para Weber, o contexto acadêmico e a questão dos elementos constitutivos da sociedade moderna possuem, de início, importância central. Ele rejeita a antiga historiografia, centrada na política e no Estado, e se volta para a análise das mudanças nas instituiçôes sociais. Nisso ele se reporta criticamente a Marx, rejeitando porém seu reducionismo econômico. Orientaçôes culturais não são simplesmente efeitos colaterais de mudanças econômicas estruturais. Desse ponto de vista, Weber está em sintonia com alguns de seus amigos acadêmicos, como Eberhard Gothein, Georg Jellinek, Georg Simmel e Werner Sombart. Gothein defendia uma história cultural e, no estudo de uma região, indicou a influência do protestantismo ascético na gênese do capitalismo (cf. Gothein, 1889, 1892). O jurista Jellinek frisava que a ideia de direitos humanos era devida menos à Revolução Francesa do que ao puritanismo norte-americano (cf. Jellinek, 1896). O filósofo e sociólogo Simmel dedicou um perspicaz estudo cultural e de psicologia social à economia monetária (cf. Simmel, [1900]* , 1989). E Sombart, em sua história do capitalismo em dois volumes, formulou teses que Weber ainda esmiuçaria por muitos anos (cf. Sombart, [1902]* 1987, vol. 2).

De um ponto de vista teórico metodológico, a "Ética protestante" de Weber dá seguimento à crítica construtiva a Marx e ao materialismo histórico, que ele já havia iniciado em seus primeiros escritos (cf. Riesebrodt, 1989). Esse diálogo inclui uma crítica ao determinismo econômico e à compreensão teleológica da história. Para Weber, a história não se constitui de progresso e libertação, mas é marcada por tendências de desenvolvimento, e também por acasos, ironias, paradoxos e consequências não intencionais da ação orientada por interesses. Não há leis históricas ocultas, que se trata de decifrar (cf. Roth e Schluchter, 1979). Não obstante, Weber não rejeita simplesmente o enfoque marxista, mas o transpõe de um contexto hegeliano a outro neokantiano.

Similar é a conversa de Weber com Nietzsche e seu entendimento das origens ascéticas da cultura moderna. Mas, no lugar da interpretação nietzschiana historicamente genérica da gênese dos ideais ascéticos no âmbito de um logro dos sacerdotes e de ressentimento, Weber identifica os estímulos
${ }^{*}$ A data entre colchetes refere-se à edição original da obra. Ela é indicada na primeira vez que a obra é citada. Nas demais, indicase somente a edição utilizada pelo autor. [N. E.] 
especificamente religiosos e históricos para a institucionalização da autodisciplina ascética (cf. Nietzsche, 1887).

O segundo contexto mais amplo em que a "Ética protestante" se situa é político. Por volta de 1900 , o capitalismo era alvo de críticas tanto da esquerda como da direita. Em consequência, o debate político e cultural também discutia a questão do endividamento. O capitalismo seria um estágio intermediário necessário da história da humanidade a caminho da terra prometida da liberdade, igualdade e fraternidade comunistas? O capitalismo seria um instrumento controlado pelo Estado para atingir a grandeza nacional e a posição de potência mundial? O capitalismo seria uma doença inglesa que destrói a cultura alemã da solidariedade com seu utilitarismo individualista? Ou se trata simplesmente da expressão da cobiça humana, sobretudo "judaica", por um impulso ao ganho imoral? Weber oferece uma resposta diferenciada, que não se encaixa em nenhum desses esquemas.

Por fim, a "Ética protestante" também pode ser lida como uma reflexão sobre os fundamentos da cultura moderna; por meio dela, Weber elabora o seu próprio colapso nervoso no contexto de sua situação familiar. Ele descreve retrospectivamente o seu colapso como um "apego desesperado ao trabalho científico, como a um talismã" e "como uma necessidade de se sentir sujeitado à carga de trabalho" (Weber, 1926, p. 249). Exatamente este tema, a internalização de uma coação ao trabalho, é analisado por Weber na "Ética protestante" como uma genealogia, especialmente quando ele constata que o puritano queria ser um homem de profissão, enquanto nós estamos obrigados a sê-lo. Ao mesmo tempo, sobressai a separação aguda entre protestantismo ascético e luteranismo. Ela serve a Weber principalmente para a caracterização da diferença entre a burguesia alemã e a anglo-saxã, mas encontra também um paralelo na descrição de sua mãe e de seu pai por Marianne Weber. O jovem Weber seguiu inicialmente o exemplo do pai, porém se aproximou decerto também em virtude da influência de sua esposa - aos ideais de sua mãe. Então, seu colapso aparece também como um processo catártico de autoconhecimento. Embora essas dimensões da ciência, da política e da vida privada estejam naturalmente sobrepostas, irei tratá-las separadamente aqui.

O capitalismo e a cultura da modernidade: o diálogo com Marx

À diferença da ciência histórica e social alemã do século XIX, já estabelecida, para Marx e seus seguidores o capitalismo representava o elemento central da modernidade. Todas as transformaçóes essenciais ocorrem em 
virtude do capitalismo e fundamentam-se em sua estrutura. Uma geração mais jovem de historiadores, economistas, filósofos e juristas, ao lado de Weber, por exemplo Georg Simmel e Werner Sombart, ligou-se criticamente a essa visão.

Sombart e Weber pertenciam à geração mais jovem da Verein für Sozialpolitik [Associação para a política social], que encarava Marx positivamente, sem contudo defender posições socialistas (cf. Krüger, 1987, pp. 71-87). Além disso, em especial Sombart havia se ocupado de Marx desde cedo; seus estudos foram elogiados por Friedrich Engels, que atestara que Sombart, diferentemente dos professores universitários alemães típicos, havia de fato compreendido Marx. Ele também estava de acordo com a tese de Sombart de que não se tratava de refutar Marx, mas sim de desenvolvê-lo (cf. Engels, 1895-1896, pp. 6-11, 37-44).

Weber também nunca foi adversário de Marx, como cientistas posteriores tentaram pintá-lo. Ernst Troeltsch (1922, pp. 314-371), amigo de Weber, documentou com argúcia a proximidade deste a Marx, e até mesmo o incluiu entre os marxistas. Weber não conhecia Marx apenas de segunda mão, mas o leu no original e tratou dele em suas aulas (cf. Weber, 1898). Além disso, as primeiras obras de Weber ocupavam-se centralmente da análise de instituições capitalistas e sua gênese (cf. MWG I/3; MWG I/5). Seu inventário da modernidade é bastante aparentado ao de Marx, quando escreve: "A atual ordem econômica capitalista é um imenso cosmos, no qual o singular nasce e que, para ele, ao menos como singular, está dada faticamente como uma capa inalterável, na qual ele tem de viver" (Weber, 1993b, p. 16).

Em suas análises do capitalismo moderno, Weber utiliza concepções que correspondem às de Marx (cf. Riesebrodt, 1989). Também para ele o capitalismo diz respeito a uma nova estrutura das relações sociais, e não a um traço psicológico dos indivíduos.

No entanto, em seus estudos sobre questôes agrárias Weber se convenceu de que o capitalismo não é explicável a partir de si mesmo. Muitas das diferenças regionais no desenvolvimento capitalista foram influenciadas por fatores extraeconômicos, como as reivindicaçôes dos trabalhadores ou sua capacidade organizatória de defender seu padrão de vida (cf. MWG I/3; Riesebrodt, 1989). Também interessaram a Weber os efeitos culturais dessa variegada transformação capitalista, acima de tudo no que dizia respeito à sua cunhagem de tipos humanos variados.

Uma avaliação crítica de Marx semelhante encontra-se em Simmel e Sombart. Eles não queriam refutá-lo, mas sim continuar desenvolvendo 
o seu enfoque no sentido de um "marxismo cultural" não determinista e adogmático (cf. Simmel, 1989, p. 719). Eles censuram o fato de Marx dar muito pouca atenção ao lado cultural e subjetivo. A acumulação do capital ainda não cria o homo oeconomicus (cf. Sombart, 1902, vol. 1, pp. 206-208). A mesma intenção anima a "Ética protestante" de Max Weber. Também aqui não se trata de refutar Marx, mas de enriquecer seu enfoque com uma perspectiva sociológico-cultural. Esse programa, como anteriormente mencionado, foi prescrito por Sombart e encontra um correspondente em afirmação similar de Georg Simmel, em sua Philosophie des Geldes [Filosofia do dinheiro]:

Do ponto de vista do método, pode-se expressar esse propósito fundamental assim: trata-se de construir um andar sob o materialismo histórico de tal modo que se conceda valor explicativo à inclusão da vida econômica entre as causas da cultura espiritual, mas que essas mesmas formas econômicas em si sejam reconhecidas como resultado de avaliações e correntes mais profundas, de pressupostos psicológicos e, também, metafísicos (Simmel, 1989, p. 13).

Para Weber, assim como para Simmel, a diferença de idealismo e materialismo não é de natureza ontológica, mas sim metodológica. Weber conhecia a conciliação de idealismo e materialismo de Simmel e é muito provável que suas próprias formulações tenham sido estimuladas por ele. Contudo, enquanto Simmel viria, mais tarde, a enfatizar a metafísica, Weber situa o enfoque socioeconômico no centro. Essas reformulações metodológicas do materialismo histórico implicam sem dúvida um afastamento fundamental em relação à filosofia da história de Marx ou de Hegel. Weber recusa a ideia de leis históricas, defende um modelo de pluralismo causal e concede às diferentes esferas sociais uma autonomia relativa. Isso implica que a história pode ser construída a partir de diversas perspectivas. Mas, sobretudo, que não se pode prever o futuro, nem mesmo em virtude da dinâmica própria das forças econômicas.

Também Weber, Sombart e Simmel viam no capitalismo uma potência central da sociedade moderna; recusavam, contudo, um determinismo econômico que tratasse o fenômeno cultural como derivação das estruturas econômicas. Fenômenos culturais não são simplesmente derivados de estruturas econômicas, mas possuem autonomia relativa. Decerto as estruturas econômicas criam pressupostos para padrões de interpretação cultural, mas esses padrões também influenciam a configuração da vida 
econômica. Fatores culturais também desempenharam um papel importante na gênese do capitalismo e em sua configuração concreta (cf. Hübinger, 1989, pp. 25-43; Hilger, 1982, pp. 442-454). Quanto ao método, não existe inevitavelmente uma causa última, apenas um encadeamento infinito de fatores.

Para Weber o capitalismo não é, de modo algum, novo, mas o moderno capitalismo empresarial burguês e seu "espírito" sem dúvida o são. Porém, o capitalismo não fez com que aquele simplesmente surgisse de si mesmo. Em "Ética protestante", Weber se volta para a investigação da gênese desse éthos.

\section{Capitalismo e protestantismo ascético}

De maneira alguma Weber foi o primeiro a constatar uma afinidade entre capitalismo e protestantismo ascético (cf. Münch, 1993, pp. 51-71). Os reis prussianos atraíram huguenotes e até mesmo menonitas pacifistas para estimular o desenvolvimento econômico. Karl Marx escreveu sobre a economia política anglo-saxã:

A economia política, essa ciência da riqueza, é, portanto, ao mesmo tempo a ciência da renúncia, da necessidade, do amealhar; e ela chega realmente a poupar ao ser humano a necessidade de ar puro ou de movimento físico. Esta ciência da indústria extraordinária é, ao mesmo tempo, a ciência da ascese, e seu verdadeiro ideal é o avarento ascético, mas usurário, e o escravo ascético, mas produtivo (1962, pp. 611-612).

A problematização de Weber vincula-se implicitamente a tais observações, na medida em que ele indaga como se originam "o avarento ascético, mas usurário" ou "o escravo ascético, mas produtivo". O sistema econômico capitalista sozinho não produz esses tipos humanos, como o demonstram o capitalismo medieval ou o capitalismo da grande burguesia do início da época moderna. Eles são o resultado de uma revolução cultural, de uma transformação drástica de um habitus ou éthos; na "Ética protestante", Weber quer perseguir as raízes, a gênese e a transformação dessa revolução cultural.

Nesse sentido, a "Ética protestante" representa um escrito programático, no qual se sonda a possibilidade e a fecundidade de uma perspectiva de pesquisa sociocultural. Em seu ensaio "Die 'Objektivität' sozialwissenschaftlicher und sozialpolitischer Erkenntnis" [A "objetividade" do conhecimento na ciência social e na política social], publicado pouco antes da "Ética 
protestante", Weber definiu a sociologia como ciência cultural e advogou metodologicamente por um enfoque socioeconômico (cf. Weber, 1982, pp. 146-214). O materialismo histórico deveria ser reformulado em uma estratégia pragmática de pesquisa.

$\mathrm{Na}$ "Ética protestante", Weber segue de fato um enfoque culturalista, já que trata de evidenciar um éthos, enquanto não moldado por um sistema econômico. Visto que para Weber materialismo e idealismo, ou visão socioeconômica e visão espiritualista, não representam opções ontológicas, mas sim metodológicas, esse processo é inteiramente legítimo.

Naturalmente, [...] o objetivo não pode ser a troca de uma interpretação cultural e histórica unilateralmente "materialista” por uma interpretação cultural e histórica espiritualista também unilateral. Ambas são igualmente possíveis, mas elas pouco servem à verdade histórica, caso elas pretendam ser não um trabalho prévio, mas sim o fecho da investigação (Weber, 1993b, p. 155).

Em relação à "Ética protestante", isso significa que, para Weber, se trata pura e simplesmente do isolamento de motivos religiosos determinados com a finalidade de elucidar sua influência sobre a cultura material moderna, sem reduzir o desenvolvimento a esses motivos: "Deve ser apenas constatado se, e em que medida, influências religiosas foram aqui de fato coparticipantes na modelagem qualitativa e quantitativa daquele 'espírito' sobre o mundo, e que aspectos concretos da cultura capitalista remontam a elas" (Idem, p. 51).

Aqui, Max Weber repudia também todas as construções históricas teleológicas, sejam idealistas ou materialistas. Nem a Reforma seria o resultado necessário de um desenvolvimento econômico precedente, nem apenas tal Reforma teria podido produzir o "espírito capitalista" ou mesmo o capitalismo (cf. Idem, ibidem). E mesmo muitos anos depois Weber ainda sente a necessidade de esclarecer:

Nenhuma ética econômica jamais foi determinada apenas religiosamente. É evidente que ela possui uma certa medida de legalidade própria pura - em grande parte determinada por elementos históricos e de geografia econômica - ante todas as posturas em relação ao mundo, condicionadas por momentos religiosos ou outros momentos (neste sentido) interiores. Mas, sem dúvida, dentre os determinantes da ética econômica pertence também sua - bem entendido: apenas uma - determinação religiosa da conduta de vida (MWG I/19, p. 85). 
Em outras palavras, Weber somente tenta identificar a ética do protestantismo ascético como um componente na formação da cultura capitalista moderna. Esse componente consiste primeiramente em uma ascese intramundana motivada puramente pela religião, da qual se desenvolveu uma ética do trabalho que até então era estranha ao capitalismo. A ideia da ascese do trabalho era mais antiga e provinha da ascese monástica, mas ela era restrita aos monastérios. $\mathrm{O}$ calvinismo e as seitas ascéticas continuaram a desenvolvê-la na concepção de um "chamamento" 2 para todos os cristãos no sentido de direcionar suas energias religiosas a um agir no mundo e a uma conduta de vida metodicamente controlada. Assim, o trabalho tornou-se relevante para a salvação. Originalmente, a internalização da ética do trabalho moderna está baseada em um temor religioso da condenação eterna. Desejava-se certificar a salvação através de uma sistematização da conduta de vida sobre fundamentos ascéticos (cf. Weber, 1993b, p. 152).

No decorrer do desenvolvimento econômico a disciplina do trabalho foi então institucionalizada e imposta aos seres humanos. Transformou-se em hábito ou norma, tornando-se "normal”. Porém, para Weber, o aspecto mais interessante da moderna ética do trabalho é que ela cria um ímpeto interno para o trabalho, um sentimento de culpa quando não se trabalha e, com isso, se "desperdiça" tempo. Tal concepção não se encontra em nenhuma forma anterior de capitalismo e não é compreensível sem as raízes religiosas.
2. O termo é "Beruf", cujo sentido é "profissão", mas à época de Lutero também podia significar "vocação", no sentido de "chamamento". Weber joga com a semântica histórica do termo "Beruf" na "Ética protestante", assim como em suas conferências "A ciência como profissão" e "A política como profissão", além de discutir o próprio desenvolvimento histórico da semântica no primeiro desses textos. Pode-se dizer que, grosso modo, quando referido à época da Reforma, o termo é mais bem vertido como "chamamento" e "vocaçăo", conforme o caso; e quando referido ao presente de Weber (ou nosso), como "profissão". [N. E.]

\section{Capitalismo e direito romano}

O debate sobre as origens do capitalismo moderno por volta de 1900 expóe o núcleo do problema da modernidade ocidental. No discurso alemão, o capitalismo não era de forma alguma um conceito marcado positivamente. Alguns o associavam à cobiça e à exploração, aos "Gründerjahre" [Anos de fundação], marcados pelo enriquecimento extremo, ascensão e queda dramáticas, quebra de bolsas e falências. A aristocracia perdeu status e precisou submeter-se às práticas econômicas burguesas. Os trabalhadores viam-se expostos a novas formas de trabalho e de dominação, especialmente com o início do taylorismo. A burguesia de cultura desprezava a estreiteza espiritual da burguesia econômica. Por isso a questão sobre quem responderia pelo capitalismo foi conduzida de forma politicamente controversa. Weber atacou sobretudo as explicações nativistas e antissemitas. O jurista Otto Gierke, por exemplo, autor do famoso Genossenschaftsrechs [Direito cooperativo], criticou o projeto de reforma do direito no Império alemão por sua falta 
de responsabilidade social (cf. Gierke, 1868-1913). Gierke responsabilizou por isso o direito romano, que teria suplantado o direito alemão, baseado na solidariedade germânica. O projeto era demasiado "romano" e não suficientemente "alemão" (cf. Gierke, 1889).

Weber objeta que essa tese é um mito. O direito romano não teria nem destruído a pretensa solidariedade germânica, nem seria responsável pela crise social do presente (cf. Weber, 1895). Além disso, no direito romano mal havia precursores para praticamente todas as instituiçóes centrais do capitalismo. Ele não foi a causa da comercialização, mas a forma preferida pura e simplesmente em virtude de sua superioridade técnica diante de outras formas jurídicas. Ademais, ocorreram processos de transformação capitalista, por exemplo na agricultura, no âmbito do direito germânico. E, finalmente, toda essa ideologia da Germânia solidária estaria baseada em fontes obscuras como a Germânia de Tácito: "O que um reacionário tendencioso como Tácito aquele burro de carga de um camponês guerreiro - inventa sobre a mulher germânica é repetido hoje por vozes semelhantes” (Weber, 1896, p. 2).

O capitalismo e "os judeus"

Embora desde cedo se tenha observado uma afinidade entre capitalismo e protestantismo ascético, havia cada vez mais correntes nacionalistas no século XIX que apresentavam o capitalismo como uma invenção dos judeus. Entre esses demagogos estava por exemplo o capelão Adolf Stoecker, fundador de um partido antissemita. Além disso, o papel dos judeus no desenvolvimento do capitalismo foi também discutido de modo controverso no âmbito científico. Por exemplo, Werner Sombart, em seus primeiros escritos, atribuía o capitalismo aos judeus (cf. Sombart, 1911; Lehmann, 1993, pp. 195-208). Em 1902 ele ainda era da opinião de que não se deveria superestimar o papel dos judeus no desenvolvimento capitalista (cf. Sombart, 1902, vol. 1, p. 390). Um ano mais tarde, já argumentava, então recorrendo a Marx, que a "raça judaica" seria especialmente predisposta ao capitalismo, pois os judeus seriam não apenas determinados e egoístas, mas também afeitos ao pensamento abstrato: "Gostaria [...] de considerar três faces do caráter nacional judeu como especialmente significativas para o papel que os judeus desempenham na vida econômica moderna: o predomínio da vontade, o interesse pessoal e o caráter abstrato de sua constituição espiritual" (Idem, 1903, pp. 128 ss.).

Com "caráter abstrato" ele alude, naturalmente, a essa característica da economia monetária enfatizada por Marx e por Simmel em sua Philosophie 
der Geldes [Filosofia do dinheiro]. Sombart chega a acusar os judeus de "idolatria do dinheiro" (Idem, p. 131; cf. Lehmann, 1993). O antissemitismo evidente de Sombart, mesmo quando ele procura esconder-se atrás de Marx, fica cada vez mais agudo, como documenta seu livro sobre Die Juden und das Wirtschaftsleben [Os judeus e a vida econômica], de 1911.

Em forte contraste com Sombart, Weber não verifica nenhuma afinidade especial dos judeus com o capitalismo. Por um lado isso tem a ver com o fato de que Weber definiu o capitalismo de modo muito mais preciso. Para Sombart, o capitalismo representa uma aspiração plebeia por enriquecimento. Trata-se primeiramente do "desenvolvimento do racionalismo econômico", que teria feito da atividade econômica um "negócio". Por isso, para Sombart, a economia colonial representa o "viveiro do espírito capitalista" (Sombart, 1902, vol. 1, p. 390). Sombart também menciona rapidamente a afinidade do protestantismo ascético (calvinismo e quakers) com o capitalismo, que ele, referindo-se a Gothein, dá como fato conhecido. Entretanto, Sombart não a toma como causa do espírito capitalista, mas antes como uma consequência de processos gerais de racionalização (cf. Idem, pp. 380-381).

Weber, em contrapartida, acentua a necessidade de distinção entre diferentes formas de capitalismo, caso se pretenda realmente compreender a qualidade nova do capitalismo moderno. O capitalismo da Antiguidade, o capitalismo do final da Idade Média e início da época moderna, assim como o capitalismo empresarial moderno, não podem simplesmente ser reduzidos a impulsos psicológicos, tais como ambição por ganho e cobiça.

No tocante aos judeus, Weber argumenta que eles mal poderiam ter participado na gênese do capitalismo moderno, em virtude de sua marginalização. Por isso desenvolveu-se entre os judeus um "capitalismo de pária", ou seja, um capitalismo mais especulativo e arriscado de um grupo discriminado. Mas, para Weber, esse "capitalismo de pária" não tinha nada a ver com características tipicamente judaicas, mas sim com sua situação social, a saber, sua exclusão das posições politicamente influentes e sua restrição a determinadas profissões (cf. Weber, 1993b, p. 5).

\section{Luteranismo e protestantismo ascético}

Weber recusa o conceito vago de capitalismo de Sombart, sobretudo porque dele resulta uma explicação psicologizante do capitalismo. Em razão de tal psicologização, Sombart não pôde ver o papel do protestantismo ascético na formação do "espírito" do capitalismo moderno. Afinal, no pro- 
testantismo ascético, assim como posteriormente no moderno capitalismo empresarial, a "ambição de ganho" não é desinibida, mas sim disciplinada, regulada e perenizada.

Weber foi sensibilizado para esse ponto de vista diferenciado principalmente pelos escritos de Gothein e de seu amigo Georg Jellinek. Em especial o livro de Jellinek sobre a "Erklärung der Menschen- und Bürgerrechte" [Declaração dos direitos do homem e do cidadão], que não deduz esses direitos politicamente da Revolução Francesa, mas sim religiosamente do puritanismo, impressionou Weber de forma profunda (cf. Jellinek, 1896; Roth, 1993a, pp. 21-22). Assim, Weber segue os mesmos caminhos para a identificação de um "espírito" do capitalismo moderno e se volta para o puritanismo.

Esse foco tem consequências para sua classificação do protestantismo. No Império alemão, o protestantismo de uma maneira geral era considerado (ao menos entre os protestantes) portador da razão e do progresso, enquanto o catolicismo era encarado como tradicionalista e autoritário. Weber via de modo diferente. Ele traça, dentro do protestantismo, uma linha nítida de separação entre o luteranismo, de um lado, e o protestantismo ascético (calvinismo, quakers, batistas, metodismo), de outro. O luteranismo é, para Weber, quase tão tradicionalista, patriarcal e autoritário quanto a Igreja católica. Mesmo no plano ético, catolicismo e luteranismo não se distinguem no essencial. A ambos falta o caráter sistemático do protestantismo ascético. Confissóes e boas açôes aliviam as almas católica e luterana, ao passo que o protestante ascético só podia assegurar a salvação eterna através de autocontrole ético estrito.

A caracterização de Weber do luteranismo remonta ao teólogo Matthias Schneckenburger (1804-1848) (cf. Graf, 1993). Para Schneckenburger, assim como para Weber, o luteranismo é tradicionalista e passivo, enquanto o calvinismo seria ativo e modernizador. Com isso Weber se posiciona explicitamente contra o representante mais significativo do luteranismo, o teólogo Albrecht Ritschl (1822-1889), cuja escola dominava a teologia protestante na Alemanha. Weber caracteriza a crítica de Ritschl a Schneckenburger como, em grande parte, anticientífica, por não abordar o luteranismo empiricamente, mas sim idealizá-lo. Além disso, Ritschl considera as tendências ascéticas no protestantismo como uma recaída no catolicismo e no tradicionalismo; com isso, ele passa ao largo da ruptura radical do protestantismo ascético com ambos (cf. Weber, 1993b, p. 89, n. 145).

De mais a mais, Weber via na política de Ritschl, em seu protestantismo cultural, em seu apoio à "Kulturkampf" de Bismarck e às leis antissocialistas, um encadeamento iníquo de religião e Estado, assim como de cultura secular 
e religiosa. Weber via decerto em Ritschl, em especial, um representante daquela burguesia satisfeita consigo mesma, à diferença da burguesia que seguiu a escola do protestantismo ascético. Weber expressa isso em uma carta de 5 de fevereiro de 1906 a Adolf von Harnack, aluno de Ritschl:

Por mais elevado que se encontre Lutero, acima de todos os outros, o luteranismo é para mim, [...] em suas formas históricas, o mais terrível dos terrores, e mesmo na forma ideal [...]. Para mim, para nós alemães, é uma formação da qual eu nunca estou incondicionalmente seguro de quanta força de apreensão da vida poderia sair dela. [...] Que nossa nação nunca tenha passado pela dura escola do asceticismo, em nenhuma de suas formas, é [...] a fonte de tudo aquilo o que eu acho odioso nela (como em mim mesmo) (MWG II/5, pp. 32-33).

Essas afirmações esclarecem por que Weber idealizou as nações anglosaxãs (cf. Roth, 1993b, pp. 83-121). Ele vê uma força em sua burguesia que falta à burguesia alemã. Uma modelagem ao menos parcial pelo protestantismo ascético e pelas seitas teria configurado caráteres mais fortes, enquanto o luteranismo e as estruturas eclesiásticas criam súditos. Por toda a "Ética protestante" Weber sublinha positivamente o caráter antiautoritário do protestantismo ascético (cf. Weber, 1993b, p. 139) e destaca sua ênfase no controle social, em contraposição à ênfase alemã do controle estatal.

Para Weber, as diferenças se explicam não apenas pelas ideias religiosas, mas acima de tudo pelas diferentes formas de organização: associações voluntárias ou igrejas. Associações voluntárias são exclusivas e por isso estabelecem requisitos estritos a todos os seus membros. Nas igrejas, ao contrário, o indivíduo está incluído desde seu nascimento; nelas, a condição de membro não está vinculada a condições éticas. Ao contrário, as igrejas, ao menos na Alemanha, tornaram-se um assunto do Estado e dos ricos, que recolhem a maior parte dos impostos, para garantir a religião ao povo (cf. Weber, 1911, pp. 201-202). A religião é, assim, instrumentalizada e não contribui para a formação de caráter, mas antes para o oportunismo e a mentira. Essa fraqueza dos alemães diz respeito a todas as classes, mas especialmente à burguesia que, no momento em que sua força de liderança nacional é exigida, fracassa e, ao contrário, se curva às estruturas autoritárias e aos líderes. A contraposição, por Weber, de uma força ascética de caráter e responsabilidade, por um lado, e fraqueza tradicionalista e oportunismo, por outro, encontra ainda um paralelo interessante na descrição dos pais de Weber por Marianne Weber. 
Entre o pai e a mãe: a "Ética protestante" como autoanálise

A "Ética protestante" possui ainda outra dimensão: ela também pode ser lida como uma autoanálise sociológico-cultural de Weber e sua família. Em sua contraposição de luteranismo e protestantismo ascético, Weber confronta-se com formas de vida e traços de caráter que também se encontram em seus pais: de um lado a mãe, devota e obediente a princípios, de outro o pai, de bem com a vida. Essas contraposições foram experimentadas por Max Weber já em sua casa paterna e tiveram uma erupção dramática em uma confrontação entre ele e seu pai acerca dos direitos de sua mãe.

Segundo Marianne Weber - sabidamente uma descrição não imparcial -, todos os anos ela e Max Weber passavam algum tempo sozinhos com a mãe dele (cf. Roth, 2001). Isso sempre teria desagradado o pai e, por ocasião da visita de 1897, ele decidiu acompanhá-la. A mãe não tinha forças para contradizê-lo, mas quando chegaram juntos a Heidelberg, Weber ficou espantado e teve um acerto de contas com o pai: "Trata-se da liberdade da mãe, ela é a mais fraca, ninguém tem o direito de violentá-la psiquicamente" (Weber, 1926, pp. 233-234).

Se o pai não admitia que sua mulher tivesse anualmente quatro ou cinco semanas de descanso com os filhos, para Max Weber não havia sentido qualquer relação sua com o pai. $\mathrm{O}$ pai fica indignado, deixa a casa em fúria e morre poucas semanas depois, sem que tenha havido uma reconciliação entre os dois. Cerca de meio ano depois Weber sofre um colapso psíquico, que o atormentará por anos a fio e o obrigará a abandonar sua cátedra em 1903. Apesar de o conflito com o pai seguramente ter contribuído para sua doença, a "Ética protestante" nos permite uma interpretação mais complexa.

Em 1894, com trinta anos de idade, Weber foi indicado para a cátedra de Economia Política em Freiburg. Três anos depois, foi nomeado para uma das cátedras mais importantes, em Heidelberg, como sucessor de Karl Knies. Ao lado de suas atividades na universidade, Weber era um cobiçado orador público e conselheiro de partidos políticos, de associações, da Igreja luterana e de instituições estatais. Ele escrevia, viajava e realizava conferências incansavelmente. Por mais que o conflito com o pai possa ter contribuído, o colapso psíquico de Weber também foi claramente causado por excesso de trabalho e esgotamento, o que hoje se costuma denominar burnout.

Mais tarde, Weber redigiu uma autoanálise, que infelizmente se perdeu. Mas seu ponto de vista é claro em uma carta conservada por Marianne, na 
qual fica evidente o nexo entre seu colapso e o tema de "Ética protestante". Weber escreve à sua mulher:

Uma doença como esta tem sim, e muito, o seu lado bom - para mim, por exemplo, abriu-se de novo o lado puramente humano da vida, e em uma medida que eu não conhecia, e que mamãe sempre dava falta em mim. [...] Minha constituição doentia manifestou-se nos anos passados em um apego desesperado ao trabalho científico, como a um talismã, sem que eu pudesse dizer em troca de quê. Ao refletir sobre o passado isso me parece muito claro, e sei, esteja eu doente ou sadio, que não será mais assim. A necessidade de me sentir sujeitado à carga de trabalho se extinguiu (Idem, p. 249).

Não há dúvida alguma de que na "Ética protestante” Max Weber também persegue as origens dessa "constituição doentia", que se expressa em uma fúria de trabalho irrefletida.

O puritano desejava ser um profissional, nós precisamos sê-lo. Pois na medida em que a ascese foi transposta da cela monástica para a vida profissional e que a moralidade intramundana começou a dominar, ela ajudou a construir aquele cosmos poderoso da ordem econômica moderna, vinculada aos pressupostos técnicos e econômicos da produção mecânica e maquinal, que determina hoje, com coação imperiosa, o estilo de vida de todo singular que nasce em meio a essa usina - e não somente os direta e economicamente ativos (Weber, 1993b, p. 153).

Até a linguagem dessa citação sugere a influência da experiência da doença de Weber, quando ele fala da "usina" e da "coação" a que estão sujeitos mesmo os que não são economicamente ativos. Não é coincidência que Weber, na mesma época, tenha posto no centro das atençôes, em outro texto, o conceito de "Kulturmenschentum" [humanidade cultural]. Weber, com esse conceito, visa à capacidade e à vontade do ser humano de assumir uma posição no mundo, conferindo, por meio de valorações, sentido à vida (cf. Weber, 1973c). Isso requer autorreflexão, em contraposição a tradicionalismo e convenção. É evidente a falta dessa mesma configuração consciente da vida para Weber no período anterior à sua doença, como já constatara criticamente seu primo, o teólogo Otto Baumgarten (cf. Roth, 2001, p. 513). Em vez de viver refletidamente o trabalho como parte da conduta e do sentido de sua vida, ele se sentia como que impulsionado "magicamente". Para satisfazer as exigências de um "Kulturmensch", precisou 
então se confrontar com a questão: qual é o modo de viver que lhe parece mais pleno de sentido?

A "Ética protestante" representa não somente uma reflexão históricocultural sobre o significado central do trabalho e suas consequências sobre o próprio Weber; em certa medida, ela também analisa as personalidades diferentes dos pais de Weber. A distinção de Weber, extraordinariamente nítida, entre luteranismo e protestantismo ascético reflete não só a sua leitura de Schneckenburger. Weber também poderia ter acentuado a diferença entre protestantismo e catolicismo, tal como fez no início da "Ética protestante", com base nas estatísticas profissionais (cf. Weber, 1993b, pp. 1-10). Contudo, a diferenciação drástica de luteranismo e protestantismo ascético também fazia sentido para ele intuitivamente, pois continha compreensōes diferentes da subjetividade, que correspondiam à visão de seus pais (cf. Graf, 1993, p. 38).

Sem dúvida seria um exagero descrever Helene Weber como uma representante do protestantismo ascético e o pai como um luterano típico (cf. Roth, 2001, p. 257). As descrições de Weber, de caráter ideal típico, são provenientes de uma época histórica totalmente diferente. Mas não pode haver dúvida de que Marianne Weber, na biografia de seu marido, acentua fortemente tais afinidades. Também a Familiengeschichte [história familiar] de Guenther Roth confirma essa impressão.

A mãe de Weber é descrita como uma mulher de consciência social marcante e de forte religiosidade interior, que teria impregnado toda a existência de Weber. Ela foi especialmente infeliz em seu casamento porque o controle patriarcal e insensível de seu marido a impedia de viver conforme sua consciência religiosa (cf. Idem, pp. 505-538). O pai de Weber é descrito como um burguês de bem com a vida, de consciência tranquila, um típico luterano de devoção cosmopolita. Ele se encaixa também na descrição de um homem que paga seus impostos eclesiásticos para preservar a religião para o povo, sem no entanto querer ser importunado por ela (cf. Idem, pp. 511-516). Para o pai de Weber, toda religião era coisa de santarrão, todo teólogo, um hipócrita (cf. Idem, p. 515).

Marianne Weber, que era muito próxima da mãe de Weber e mais distante do pai, confirma a imagem. Ela caracteriza o pai de Weber como um patriarca que mantinha sua esposa em dependência econômica, embora grande parte do patrimônio proviesse de sua herança (cf. Weber, 1926, p. 149). Não surpreende que ele reprovasse os movimentos de igualdade das mulheres, em que Marianne Weber era bastante engajada, com o apoio de Max Weber (cf. Idem, p. 151). Apesar disso, Marianne também descreve o sogro como: 
Totalmente honrado, completamente livre de egoísmos na política e no cargo que ocupava, e além disso sábio, bondoso, caloroso e amável, quando tudo corria segundo seus desejos; mas um típico burguês, satisfeito consigo e com o mundo. Ele recusa por princípio o reconhecimento dos aspectos problemáticos da vida (Idem, p. 67).

Além disso, Marianne descreve o sogro como "um homem predisposto ao prazer e à alegria" (Idem, p. 245), que possuía "a consciência tranquila de um homem de posses de sua classe ante os próprios luxos - em nada modestos" e que não era "sensível à caridade" (Idem, pp. 149-150).

Em contraposição, Marianne caracteriza a mãe de Weber, Helene, como uma "mulher encantadora, graciosa, amorosa e, apesar de sua seriedade interior, tão forte, arrebatadora e alegre" (Idem, p. 64). Ela é aberta a novos temas, socialmente engajada e possui, no geral, uma personalidade bem mais complexa do que seu marido. Os círculos burgueses do marido não lhe importavam; em compensação, interessava-se pela geração mais nova, como os amigos de seu filho, que se engajava ativamente em movimentos sociais, em especial na questão dos trabalhadores.

Essa comunidade de interesses religiosos e sociais, que a liga a Otto Baumgarten, [Paul] Göhre, [Friedrich] Naumann, [Martin] Rade, corre como uma fonte de vida nova e fresca no início de seu outono. Mas seu marido não se junta a esses jovens e permanece o que é: um burguês liberal (Idem, pp. 150-151).

Confrontemos agora essa descrição dos pais com a caracterização das disposiçôes psicológicas do luteranismo e do protestantismo ascético.

A religiosidade luterana manteve inabalada [... a vitalidade inocente das açôes impulsivas e da vida afetiva ingênua: faltava aquele estímulo ao autocontrole constante e, com isso, àquela regulamentação planejada da própria vida, tal como contida na doutrina sombria do calvinismo (Weber, 1993b, pp. 86-87).

Em uma carta ao irmão mais novo, Weber escreve, a respeito de seu conflito com o pai, que com certeza teriam sido cometidos erros de todos os lados, e também do dele. A mãe, porém, não podia ter feito nada, a não ser "seguir sua natureza e sua consciência". Se ela tivesse agido de maneira mais enérgica, seu marido teria então "se acostumado" a isso (cf. Weber, 1926, p. 246). Em outras palavras, a mãe seguiu sua consciência, enquanto o pai seguiu seus hábitos. 
Max Weber não era de forma alguma apenas um observador ou alguém indiretamente afetado pelo drama do casamento de seus pais. Tratava-se também dele mesmo e de sua orientação na vida. Pois no início ele seguiu amplamente o modo de vida do pai - para o pesar da mãe. Como ele, Weber estudou direito e tornou-se membro da mesma corporação estudantil em Heidelberg. Quando, após o primeiro semestre em Heidelberg, Weber retornou a Berlim, havia adquirido uma barriga de cerveja e uma cicatriz no rosto. A reação de sua mãe foi clara: deu-lhe um tapa no rosto (cf. Idem, p. 74). Ela não queria ver seu filho assim - ele estava parecido demais com o pai. Marianne Weber relata:

Naqueles anos permanecia em aberto se o "Grande" se decidiria pelo tipo do pai ou pelo da mãe. Ela já tinha o vago sentimento de que, em algum momento, tal escolha teria de ser feita - tão logo ele tomasse as rédeas de si mesmo e começasse a elaborar conscientemente sua própria personalidade (Idem, p. 66).

Max Weber, no entanto, transformou-se sobretudo pela influência de sua mulher Marianne, que estava muito próxima da sogra e de seus "princípios heroicos" (Idem, p. 67). Com a confrontação com o pai, Weber decidiuse pela mãe. A escrita da "Ética protestante" possibilitou então a Weber trabalhar, com distância histórica e estranhamento, a constelação familiar. Pai e mãe foram situados histórica e culturalmente em suas respectivas concepções de vida. O conflito entre pessoas foi objetivado em uma confrontação de diferentes posturas perante o mundo. A dimensão pessoal recua, possibilitando a compreensão cultural, e ao mesmo tempo ajuda Weber a tomar sua própria decisão sobre uma vida conduzida de modo refletido e consequente, e a fundamentá-la objetivamente. É claro que Weber não se torna um protestante ascético, mas os parâmetros com que a partir de então ele passa a medir a si mesmo e aos outros - dedicação à coisa, ausência de ilusões, coerência, força de caráter - são de maneira muito clara fortemente modelados pelo protestantismo ascético.

Da vocação religiosa à profissão mundana

Neste ensaio tentei indicar diversas perspectivas que permitem uma leitura mais complexa da "Ética protestante": uma científica, uma política e uma pessoal. Esse esboço de forma alguma reivindica a completude; certamente outras dimensões desse texto complexo podem ser descobertas 
e perseguidas. Por mais imperfeita que seja a "Ética protestante", vista de uma perspectiva sociológica, ela representa sem dúvida um texto-chave para a compreensão de Weber e de sua obra.

Por um lado, é a precursora de seus estudos comparativos sobre a "Ética econômica das religiōes universais". Neles Weber se volta para a questão de saber se as religiōes da China e da Índia teriam potencial de desenvolver uma ascese intramundana como fenômeno de massa e, se esse não fosse o caso, quais seriam as razōes para tanto. Além disso, ele persegue o início dos processos de racionalização ocidental no judaísmo antigo. Tudo isso é sistematizado então em "Economia e sociedade" (cf. também Kippenberg e Riesebrodt, 2001). Mas, por trás dessas questôes, que se referem somente na aparência à gênese de um éthos capitalista moderno, radica também um forte interesse de Weber por diferentes posturas diante do mundo, pelas diferentes interpretaçōes acerca do que pode significar ser humano: "É verdade que o curso do destino da humanidade balança o coração de quem dele vislumbra um fragmento. Mas ele faz melhor em guardar para si os seus pequenos comentários pessoais, tal como se faz ao contemplar o mar e as altas montanhas..." (Weber, 1920a, p. 14).

Quem somos nós e quem poderíamos ser, depende de condiçóes guiadas pelo destino, que nós mesmos não controlamos. Cada cultura cria um tipo de ser humano e não há um lugar neutro, do qual pudesse ser avaliado comparativamente.

Mas a "Ética protestante" não é somente a precursora da "Ética econômica das religiōes universais", mas também - o que é facilmente esquecido - dos ensaios "Política como profissão" e "Ciência como profissão", nos quais Weber se ocupa da questão de como se pode atribuir sentido à vida sob as condições de uma modernidade modelada pelo capitalismo e pela burocracia. Aqui ele também tematiza os dilemas éticos que já havia abordado no final da "Ética protestante".

$\mathrm{Na}$ "Ética protestante", Weber analisa inicialmente como o novo éthos supera o tradicionalismo, na medida em que o trabalho obtém uma consagração religiosa que antes não lhe era própria. Ela se transforma em uma "vocação". Isso implica um desligamento do trabalho da tradicional satisfação das necessidades. Simplesmente não se para de trabalhar, quando a demanda está suprida: "O ser humano relaciona-se com o ganho como o fim de sua vida, e não mais o ganho relaciona-se com o ser humano como um meio para o fim da satisfação de suas necessidades materiais de vida" (Weber, 1993b, p. 15). 
E adiante:

Aqui não é indispensável apenas um sentimento de responsabilidade desenvolvido, mas também uma consciência que, ao menos durante o trabalho, se liberte da questão constante de como se poderia ganhar o salário habitual com um máximo de conforto e um mínimo de desempenho, e assim leve a cabo o trabalho como se ele fosse um fim em si mesmo absoluto - como uma "vocação". Tal consciência não é algo naturalmente dado. Ela também não pode ser criada imediatamente por um salário alto ou baixo, mas somente pode ser o produto de um "processo educativo" de longa duração (Idem, p. 21).

Esse processo educativo modelou de uma nova forma os seres humanos no capitalismo moderno. O éthos do protestantismo ascético originou sem dúvida uma postura de base religiosa perante a vida. A institucionalização desse éthos no capitalismo industrial destruiu, contudo, essa base religiosa e com isso esvaziou de sentido esse éthos. Na melhor das hipóteses, ele continua existindo como vaga sensação de um sentimento de dever ou como coação. Mal se pode conferir sentido ao próprio impulso aquisitivo, que é antes levado a cabo como competição, esporte (cf. Idem, p. 154). Ao mesmo tempo, a divisão do trabalho e a especialização forçadas tornaram impossível o velho ideal do ser humano modelado universalmente. Sob tais condições, como é possível escolher uma profissão e enxergar nela o sentido de sua existência? São essas as questões de que Weber se ocupa em suas duas conferências, originalmente proferidas a estudantes, "A ciência como profissão" e "A política como profissão" - e aqui me concentrarei apenas na primeira.

Weber inicia com um inventário objetivo das instituições universitárias e seu real funcionamento. Ele as retrata como uma rotina burocrática em que a mediocridade conta mais que o desempenho. Além disso, seu prognóstico é de que a universidade irá desenvolver-se cada vez mais no sentido de uma empresa de prestação de serviços. Sob tais condições, como a ciência pode ser uma "profissão" no sentido de uma "vocação"?

Weber admite que é difícil. Vivemos em um mundo desencantado. A própria visão profética de um cosmos uno e pleno de sentido, que outrora substituiu o politeísmo e reivindicou um posicionamento ético unificado diante do mundo, agora está destruída. Aqui não ajudam nem o escapismo para mundos de sonho, nem a busca de "experiências" ou o anseio por novas profecias e líderes carismáticos. Em vez disso, os velhos deuses retornaram na forma de potências impessoais e precisamos nós mesmos escolher o "deus" 
ao qual queremos servir, seja ele o deus "política", "ciência", "economia" ou "arte".

Ao dedicar-se à ciência, o que é preciso para ser um cientista? Primeiramente deve-se desistir do ideal fáustico do gênio universal. Tal época se foi e não traz mais gênios, somente diletantes. A especialização na ciência é uma tendência irreversível. Todos estamos condenados a ser "especialistas". Contudo, o que torna a atribuição de sentido na ciência especialmente difícil é o fato de que nossos resultados têm vida curta, e assim deve ser. Enquanto o trabalho artístico recebe apreço por longos períodos de tempo, a ciência produz sempre resultados provisórios, que serão superados por novas pesquisas ou serão vítimas de novas problematizações. O pressuposto para se obter resultados de valor é portanto a entrega incondicional à coisa de que cada um se ocupa a cada momento. Somente assim a profissão científica terá significado para aquele que a cumpre. Apenas aquele que se entrega sem vaidade a um objeto, mas com paixão, possui "personalidade" na ciência.

Ao final da "Ética protestante", Weber faz referência ao cenário nietzschiano do "último homem" e alerta para os "especialistas sem espírito" e os "sensualistas sem coração" (Idem, p. 154). Em "A ciência como profissão", por outro lado, ele advoga pelos especialistas, mas a favor daqueles com espírito e acima de tudo com entrega apaixonada. Em vez de esperar pela salvação vinda de novos profetas ou redentores, devemos carregar o peso da autonomia e assim nos conservar no cotidiano. Isso é, ao mesmo tempo, destino e possibilidade.

A "Ética protestante" de Weber não é evidentemente um texto de história econômica ou cultural que nos convida a testar uma hipótese. Muito pelo contrário, trata-se de uma obra extremamente complexa, que com certeza só é compreensível por meio de sua contextualização.

\section{Resumo}

A ética protestante no contexto contemporâneo

$\mathrm{O}$ artigo propõe uma leitura em vários planos do texto "A ética protestante e o espírito do capitalismo", de Max Weber, procurando indicar diferentes camadas e possibilidades de análise. Para tanto, propõe uma análise do texto em três planos diferentes e complementares: o político, o científico e o pessoal. Discute, assim, as diferentes versões e os diferentes contextos de publicação, abordando o diálogo de Weber com Marx e as relações do capitalismo com o protestantismo ascético. Por outro lado, destaca em que medida o texto pode e deve ser lido como uma espécie de autoanálise de Weber. 
Palavras-chave: Max Weber; Max Weber Gesamtausgabe; Ética protestante; Protestantismo ascético; Capitalismo; Autoanálise.

\section{Abstract}

\section{The Protestant ethic in the contemporary context}

The article proposes a multi-level reading of The protestant ethic and the spirit of capitalism by Max Weber, looking to identify different textual layers and analytic possibilities. Hence it pursues an analysis of the text at three different and complementary levels: the political, the scientific and the personal. It discusses the different versions of the text and the different contexts of publication, including an exploration of Weber's dialogue with Marx and the relations between capitalism and ascetic Protestantism. At the same time it highlights the extent to which the text can and should be read as a kind of self-analysis by Weber.

Keywords: Max Weber; Max Weber Gesamtausgabe; Protestant ethic; Ascetic protestantism; Capitalism; Self-analysis. 